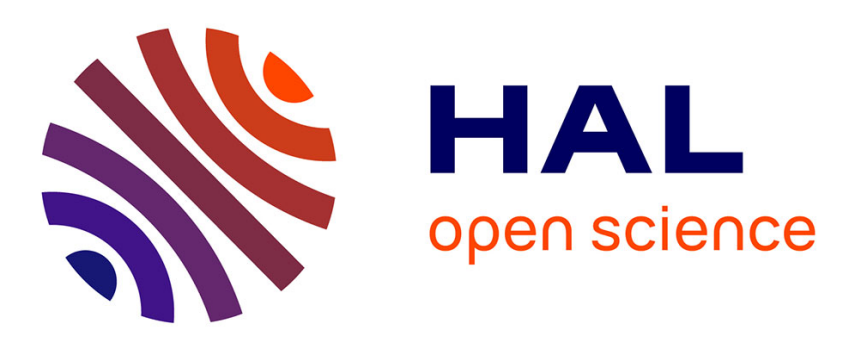

\title{
Obesity and Corticosteroids: $11 \beta$-Hydroxysteroid Type 1 as a Cause and Therapeutic Target in Metabolic Disease
}

\author{
Nicholas Michael Morton
}

\section{To cite this version:}

Nicholas Michael Morton. Obesity and Corticosteroids: 11 $\beta$-Hydroxysteroid Type 1 as a Cause and Therapeutic Target in Metabolic Disease. Molecular and Cellular Endocrinology, 2009, 316 (2), pp.154. 10.1016/j.mce.2009.09.024 . hal-00550246

\section{HAL Id: hal-00550246 https://hal.science/hal-00550246}

Submitted on 25 Dec 2010

HAL is a multi-disciplinary open access archive for the deposit and dissemination of scientific research documents, whether they are published or not. The documents may come from teaching and research institutions in France or abroad, or from public or private research centers.
L'archive ouverte pluridisciplinaire HAL, est destinée au dépôt et à la diffusion de documents scientifiques de niveau recherche, publiés ou non, émanant des établissements d'enseignement et de recherche français ou étrangers, des laboratoires publics ou privés. 


\section{Accepted Manuscript}

Title: Obesity and Corticosteroids: $11 \beta$-Hydroxysteroid Type 1 as a Cause and Therapeutic Target in Metabolic Disease

Author: Nicholas Michael Morton

PII: $\quad$ S0303-7207(09)00521-8

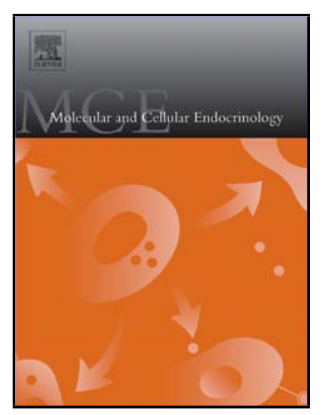

DOI: doi:10.1016/j.mce.2009.09.024

Reference: MCE 7336

To appear in: Molecular and Cellular Endocrinology

Received date: $1-12-2008$

Revised date: 16-9-2009

Accepted date: 28-9-2009

Please cite this article as: Morton, N.M., Obesity and Corticosteroids: 11ßHydroxysteroid Type 1 as a Cause and Therapeutic Target in Metabolic Disease, Molecular and Cellular Endocrinology (2008), doi:10.1016/j.mce.2009.09.024

This is a PDF file of an unedited manuscript that has been accepted for publication. As a service to our customers we are providing this early version of the manuscript. The manuscript will undergo copyediting, typesetting, and review of the resulting proof before it is published in its final form. Please note that during the production process errors may be discovered which could affect the content, and all legal disclaimers that apply to the journal pertain. 
Review

Obesity and Corticosteroids: $11 \beta$-Hydroxysteroid Type 1 as a Cause and Therapeutic Target in Metabolic Disease

Nicholas Michael Morton*nik.morton@ed.ac.uk

University of Edinburgh, Centre for Cardiovascular Sciences, 47 Little France Crescent, Edinburgh EH16 4TJ, UK

*Tel.: +44 131242 6691; fax: +44 1312426779.

\section{Abstract}

The metabolic abnormalities found associated with high blood glucocorticoid levels (eg rare Cushing's syndrome) include insulin-resistance, visceral obesity, hypertension, dyslipidaemia and an increased risk of cardiovascular diseases. The same constellation of abnormalities is found in the highly prevalent idiopathic obesity/insulin-resistance- (metabolic) syndrome. It is now apparent that tissuespecific changes in cortisol metabolism explain these parallels rather than altered blood cortisol levels. Primary among these changes is increased intracellular glucocorticoid reactivation, catalysed by the enzyme $11 \beta$-hydroxysteroid dehydrogenase type (HSD)-1 in obese adipose tissue. Liver, skeletal muscle, endocrine pancreas, blood vessels and leukocytes express $11 \beta$-HSD1 and their potential role in metabolic disease is discussed. The weight of evidence, much of it gained from animal models, suggests that therapeutic inhibition of 11 $\beta$-HSD1 will be beneficial in most cellular contexts, with clinical trials supportive of this concept.

Keywords: Obesity; Glucocorticoid; 11-hydroxysteroid; Metabolic syndrome; Therapy; Adipose; Liver; Diabetes; Insulin resistance 


\section{The Obesity Problem.}

Obesity and insulin-resistance (metabolic)-syndrome is one of the greatest healthcare challenges of the $21^{\text {st }}$ century. The associated cardiovascular diseases are the largest cause of premature death in the world (World Health Organisation (WHO), 2008a). WHO's projection indicated that globally in 2005 approximately 1.6 billion adults (age 15+) were overweight and at least 400 million adults were obese. Projections for 2015 are staggering, with an approximated 2.3 billion adults overweight and more than 700 million obese. At least 20 million children under the age of 5 years were overweight globally in 2005 (WHO, 2008b). Further, although obesity was once considered a problem only in high-income countries, overweight and obesity are now dramatically on the rise in low- and middle-income countries, particularly in urban settings (WHO, 2008b). With the recent high profile problems associated with promising anti-obesity/diabetes treatments such as Rimonabant (see eg. Christensen et al., 2008) and Rosiglitazone (see eg. Singh and Loke, 2008), the unmet clinical need will continue to grow in the coming years. This review discusses the evidence for the pathophysiological role of increased glucocorticoid action, mainly within adipose tissue, catalysed by the intracellular enzyme $11 \beta$-hydroxysteroid deydrogenase type 1 (11 $\beta$-HSD1) and its potential as a future anti-obesity treatment. The role of the enzyme in other important tissues associated with obesity, metabolic and cardiovascular disease are also briefly highlighted. For more detailed discussion of the potential factors regulating $11 \beta$-HSD1 levels in cells, readers are referred to recent reviews by others (Tomlinson et al., 2004).

\section{Adipose tissue dysfunction in obesity.}

The most fundamental advance in obesity research in recent years centres around the concept that obese adipose tissue is characterised by a chronic, low grade inflammation that exacerbates, and may underlie, insulin resistance and metabolic disease (Hotamisligil 2006). Increased adipose tissue mass is a source of many proinflammatory cytokines (adipokines), chemoattractants, prothrombotic, vasoactive and angiomodulatory factors, some of which have been directly linked to tissue and systemic insulin-resistance such as TNF- $\alpha$ (Hotamisligil et al., 1993) interleukin (IL)6 (Rotter et al., 2003), monocyte chemoattractant protein (MCP)-1 (Sartipy and Loskutoff 2003 ), serum amyloid (SA)-A3 (Lin et al., 2001), macrophage inhibitory 
factor (MIF) (Atsumi et al., 2007), CXC motif chemokine ligand-14 (Nara et al., 2007) and many others (Figure 1). There is also a reduction in insulin-sensitising adipokines such as adiponectin in obesity (Berg et al., 2001, Yamauchi et al., 2001). Increased infiltration of macrophages (Xu et al., 2003, Weisberg et al., 2003, Zeyda et al., 2007), dendritic cells (Nguyen et al., 2007) and T cells of the adaptive immune system (Wu et al., 2007), particularly cytotoxic CD8+ Tcells (Rausch et al., 2008), further contribute to inflammatory processes in obesity. Hypertrophic, insulinresistant adipocytes disgorge free fatty acids, hi-jacking the pro-inflammatory innate immune system bacterial lipotoxin toll-like receptors (TLR)-2 and 4 on both macrophages and adipocytes (Lin et al., 2000, Shi et al., 2006, Song et al., 2006, Nguyen et al., 2007). Cellular stress mechanisms (Wellen and Hotamisligil 2005) within the lipid-laden adipocytes induce a hybrid necrotic/apoptotic-like state (Cinti, et al., 2005, Murano et al., 2008), associated with localised hypoxia (Ye et al., 2007, Rausch et al., 2008) that may be secondary to impaired angiogenesis in the rapidly expanding adipose tissue (Lijnen 2008). This ultimately causes systemic insulin resistance (Figure 1) in muscle, liver and locally in the adipose tissue itself (Hotamisligil et al., 2006).

\section{Glucocorticoid effects on adipose tissue.}

Cushing's syndrome, caused by excessive circulating glucocorticoids, and common idiopathic obesity/insulin resistance-syndrome ('metabolic syndrome') share some striking similarities. For example, excess cortisol production and release in Cushing's syndrome causes pronounced visceral fat deposition. Visceral adiposity carries with it the highest cardiovascular-disease risk relative to fat accumulated elsewhere (Kissebah et al., 1982, Wajchenberg 2000). Glucocorticoids thus have distinct effects on different fat depots, and cause an unfavourable redistribution of fat. Glucocorticoid receptors (GR) are more highly expressed in visceral fat (Pedersen et al., 1994) and therefore (circulating) glucocorticoids likely have a greater impact on both metabolic responses (insulin resistance, lipolysis) and adipokine expression and release through the portal blood to the liver. A number of cellular processes may be negatively affected by excessive glucocorticoid action within adipocytes (Figure 2).

Glucocorticoids drive accelerated preadipocyte differentiation and adipocyte fat accumulation (Ailhaud et al., 1991, Gaillard et al., 1991, Wolf 1999, Bjorntorp and 
Rosmond 2000). Glucocorticoids directly impair insulin sensitivity in adipocytes (Sakoda et al., 2000) and promote free fatty acid release from mature adipocytes through hormone sensitive lipase (HSL)-mediated lipolysis (Slavin et al., 1994). Activity of the cellular energy sensor AMPK system is inhibited by glucocorticoids and may contribute to central fat deposition in Cushing's disease (Christ-Crain et al., 2008), explaining the seemingly paradoxical increase in fat accumulation through fatty acid synthesis, as well as increased lipolysis through HSL. Glucocorticoids can cause both release and inhibition of inflammatory mediators from adipocytes. For example, dexamethasone (a potent synthetic glucocorticoid) treatment of the mouse 3T3-L1 adipocytes increased expression and secretion of proinflammatory SAA-3 (Fasshauer et al., 2004) and prothrombotic PAI-1 (Udden et al., 2002) but suppressed IL-6 (Fasshauer et al., 2003) and adiponectin (Fasshauer et al., 2003b). As well as affecting cytokine expression and secretion, glucocorticoids may activate cellular stress and survival mechanisms in adipocytes, such as tribbles homolog (TRB)-3 signalling (Yacoub et al., 2006), which impairs insulin signalling (Koo et al., 2004). Further, cellular stress pathways are positively regulated by the glucocorticoidinducible (Boruk et al., 1998) C/EBP- $\beta$ (Arai et al., 2007). These cellular and endoplasmic reticulum stress mechanisms are directly linked to insulin-resistance and diabetes in obesity (Ozcan et al., 2004). Glucocorticoids therefore regulate many adipocyte functions, from differentiation and lipid accumulation, cellular stress, and insulin resistance through to proinflammatory cytokine release and represent an attractive molecular link between the metabolic abnormalities found in common between Cushing's and metabolic syndrome (Figure 2). However, despite these phenotypic parallels, circulating glucocorticoids are generally not elevated in idiopathic obesity /metabolic syndrome (Seckl and Walker, 2001).

\section{Glucocorticoid levels in obesity.}

Although plasma cortisol levels appear normal in the metabolic syndrome or obesity, there are exaggerated dynamic cortisol responses (Pasquali et al., 1999) In particular, abdominal obesity associates with increased urinary free cortisol excretion and increased total cortisol production rates (Marin et al., 1992, Stewart et al., 1999). These data suggest that whilst disturbances in feed-forward drive, feedback inhibition of the HPA axis and altered peripheral clearance in the liver (Andrew et al., 1998) occur in obesity, with subtle differences between manifestations of the metabolic 
syndrome, there is no strong evidence for enhanced cortisol secretion as a driver of the adipose abnormalities in humans (Morton and Seckl 2008).

Nevertheless, a large body of evidence for the critical permissive role of glucocorticoids in the development of obesity and metabolic disease was demonstrated in rodent obesity models (Shimomura et al., 1987, Dallman et al., 2004) underscoring the functional importance of glucocorticoids in adipose pathophysiology. Ultimately, in the absence of any evidence for high circulating glucocorticoid levels in common obesity, local tissue-level conversion of cortisone to cortisol by $11 \beta$-hydroxysteroid dehydrogenase type 1 emerged as being strongly implicated in determining local GR activation, offering an explanation for the parallels between Cushingoid- and idiopathic obesity.

\section{1ß-Hydroxysteroid dehydrogenase type 1.}

$11 \beta$-hydroxysteroid dehydrogenase type 1 (11ß-HSD1) catalyses the activation of glucocorticoids (cortisol in humans, corticosterone in rodents) from inactive 11-keto steroids (cortisone, 11-dehydrocorticosterone) within intact cells. $11 \beta$-HSD1 is widely expressed in many tissues (Ricketts et al., 1998) most highly in liver (Tannin et al., 1991) and at lower levels in adipose tissue (Bujalska, et al., 1997, Rask et al., 2001, 2002) and in other organs and cells with high GR expression (Whorwood et al., 1991). The activation potential of $11 \beta$-HSD1 is dependent on the provision of NADPH co-factor by the co-localised enzyme hexose-6-phosphate dehydrogenase (H6PDH) (Atanasov et al., 2004, Lavery et al., 2006), in the absence of which 11 $\beta$ HSD1 acts as a dehydrogenase, inactivating cortisol.

\section{1 $\beta$-Hydroxysteroid dehydrogenase type 1 in adipocytes.}

11ß-HSD1 is expressed in mouse, rat (Napolitano et al., 1998) and in human adipose tissue (Bujalska et al., 1997, Morton and Seckl 2008). 11ß-HSD1 levels increase with differentiation of mature adipocytes (3T3F442A and 3T3-L1 cells) - and the reaction direction is exclusively 11-ketoreduction (Napolitano et al., 1998). Unlike the undifferentiated $3 \mathrm{~T} 3$ cells, primary mouse preadipocytes express abundant 11 $\beta$-HSD1 (De Sousa Peixoto et al., 2008). Unexpectedly, 11ß-HSD1 reductase activity levels (not protein) were higher in visceral adipose preadipocytes - compared to peripheral 
fat preadipocytes (De Sousa Peixoto et al, 2008). This suggested that an as yet unidentified post-transcriptional level effect might exaggerate the cortisol reactivation potential of $11 \beta$-HSD1 in visceral fat preadipocytes, potentially augmenting the accumulation of visceral adiposity in obesity. This may also occur in human adipose stromal cells which express H6PDH uniformly highly throughout differentiation whilst 11ß-HSD1 expression increases (Senesi et al., 2008), although previous studies suggested increasing H6PDH expression may control a switch in enzyme directionality throughout differentiation (Bujalska et al., 2002). Further clarification of this will be needed in human cells. The discrepancy between 11ß-HSD1 mRNA, protein and activity levels (De Sousa Peixoto et al., 2008) has also been noted in human studies (Goedecke et al., 2006). An explanation for this, at least in human omental explants, seems to be at the level of H6PDH activity as discussed below (Lee et al., 2008).

Metabolism of oxysterols by $11 \beta$-HSD1 in adipose - the recent discovery that $11 \beta$ HSD1 could metabolise oxysterol metabolites in liver (Schwiezer et al., 2004) has been extended to adipose tissue (Wamil et al., 2008). Here, competitive inhibition of $11 \beta$-HSD1 activity was seen with 7-ketocholesterol, and oxysterol metabolites were sequestered into mature 3T3 adipocytes. 7-ketocholesterol inhibited adipocyte differentaiton in vitro and suggested that in obesity or dyslipidaemia, where adipose tissue acts as a sump for the atherogenic 7-oxyterols, high adipose $11 \beta$-HSD1 in obesity might interfere with neutralisation of these potent atherogenic metabolites (Figure 2), although it remains to be determined what the relative substrate levels are in adipose tissue of obese and dyslipidaemic disease states.

$11 \beta$-HSD2 in adipose - the prevailing view was that levels of the type $211 \beta$-HSD, which inactivates cortisol with high affinity and is expressed at high levels in mineralocorticoid receptor (MR) target tissues (this receptor's ligand binding domain cannot distinguish between cortisol and aldosterone) was not expressed in adipose tissue. However, a recent study suggests $11 \beta$-HSD2 is expressed in rat adipocytes and stromal cells, is induced by dietary fat in rats and correlated with adiposity and insulin resistance whereas 11 $\beta$-HSD1 did not (Milagro et al., 2007). 11 $\beta$-HSD2, whilst consistently lower than $11 \beta$-HSD1 was also reduced in adipose from obese women (Engeli et al., 2004) and may be expressed predominantly in the stromal compartment 
of human visceral fat (Lee et al., 2008). This would make sense as aldosterone has been implicated in preadipocyte differentiation and adipokine expression in adipose, among other functions (Guo et al., 2008, Hirata et al., 2009). If confirmed, this may also account for the increased cortisone levels found in the portal vein (along with intestinal 11 $\beta$-HSD2) of obese humans (Basu et al., 2008). Future studies are needed to confirm the relevance of endogenous $11 \beta$-HSD2 and aldosterone activity in adipose, but this may reveal a novel link between obesity and that activated reninangiotensin-aldosterone system in hypertension.

\section{Adipose 11ß-HSD1 in obesity.}

Obese rodents with leptin receptor (Zucker Leprfa/fa rats) or leptin gene mutations (Lepob/ob mice) exhibited increased adipose 11ß-HSD1 (Livingstone et al., 2000, Masuzaki et al., 2001, Morton et al., 2004b). In humans, 11 $\beta$-HSD1 mRNA and activity is increased in subcutaneous abdominal adipose tissue of obese subjects both in vivo and in vitro (Rask et al., 2001, 2002, Lindsay et al., 2003, Wake et al., 2003, Kannisto et al., 2004, Goedecke et al., 2006, Michailidou et al., 2007, Paulsen et al., 2007 - not a comprehensive list) with few exceptions (Tomlinson et al., 2002).

Further studies have directly confirmed increased 11 $\beta$-HSD1 activity using tissue microdialysis in obese subcutaneous adipose tissue (Sandeep et al., 2005). Recent studies suggest that in some cases $11 \beta$-HSD1 mRNA levels are also increased in visceral omental adipose tissue of obese women and are a strong predictor of fat cell size in this visceral depot (Desbriere et al., 2006, Michailidou et al., 2007, Paulsen et al., 2007). 11 $\beta$-HSD1 might impact differentially on the pathophysiology of distinct fat depots in obesity. Peripheral adipose depots (equivalent to upper body fat in humans) express the highest levels of 11 $\beta$-HSD1 (Morton et al., 2004a). Upper body fat contributes most to the circulating free fatty acid pool (Jensen 2007) suggesting perhaps a dominant role for $11 \beta-H S D 1$ in regulation of free fatty acids here. On the other hand, adipokine release occurs more actively in visceral fat, where GR levels are higher (Pedersen et al., 1994, Masuzaki et al., 2001), suggesting 11 $\beta-H S D 1$ activity might primarily affect adipokine profiles in this depot. The further impact that elevated visceral fat glucocorticoid action and production would have on the portal supply of adipokines and fatty acids to the liver remains important to determine (see below). 
It is of note that mice and rats with obesity of polygenic origin have low (Morton et al., 2005) or unchanged (Kloting et al., 2006) adipose, but elevated liver (Morton et

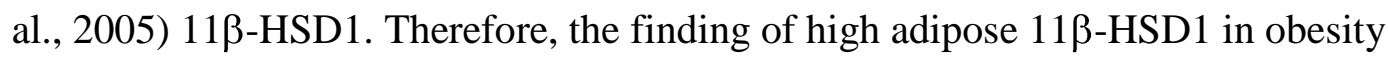
may not be universal and tissue 11 $\beta$-HSD1 levels must be carefully considered in each model system as well as in humans (Tomlinson et al, 2002).

\section{Visceral fat 11 $\beta$-HSD1 - and portal insulin resistance.}

Transgenic mice with adipose-specific 11 $\beta$-HSD1 overexpression exhibited higher portal corticosterone, indicating the possibility of a paracrine effect of excess cortisol/corticosterone to modulate liver function (Masuzaki et al., 2001). However, measurement of portal vein cortisol in dogs (Basu et al., 2006) and humans indicated that visceral (fat) 11ß-HSD1 is unlikely to contribute to portal cortisol levels (Stimson et al., 2008, Basu et al., 2008). Unexpectedly, the visceral compartment (visceral fat, gut, pancreas, spleen) actually released cortisone into the portal vein in obese humans (Basu et al., 2008). This could be due to intestinal 11 $\beta$-HSD2 activity, or perhaps adipose stromal 11ß-HSD2 (Engeli et al., 2004, Milagro et al., 2007, Lee et al., 2008). In rodent obesity, the largest relative increase in fat depot 11 $\beta$-HSD1 expression (Livingstone et al., 2000, Masuzaki et al., 2001, Morton et al., 2004a) occurs in the visceral fat. Moreover, glucocorticoid 'reactivation potential' is greatest in preadipocytes from this depot, despite lower 11 $\beta$-HSD1 protein levels than peripheral preadipocytes (De Sousa Peixoto et al., 2008). Future studies will be needed to determine whether this effect occurs in humans - with the intriguing recent observation that dexamethasone and insulin increased H6PDH mRNA in human omental fat organ culture, leading to increased 11 $\beta$-HSD1 reductase activity, but down-regulation of 11 $\beta$-HSD1 protein (Lee et al., 2008). If no hypothetical glucocorticoid 'spillover' occurs, then the detrimental effect of increased visceral fat $11 \beta$-HSD1 in humans will be down to intracellular regulation of cellular stress, insulin resistance and adipokine and free fatty acid release into the portal system (Figure 2).

\section{Lessons from transgenic models of altered adipose glucocorticoid action.}


Adipose 11 -HSD1 overexpression - to test the hypothesis that high adipose $11 \beta$ HSD1 might be causal of obesity and metabolic disease 11 $\beta$-HSD1 was selectively expressed using the aP2 promoter (Masuzaki et al., 2001). Adipose 11 $\beta$-HSD1 overexpression (aP2-11 $\beta$-HSD1 mice) was comparable to that in obese humans (2-3 fold). Corticosterone levels were similarly raised in adipose tissue and in the portal but not systemic circulation. Transgenic aP2-11 $\beta-H S D 1$ mice exhibited intraabdominal obesity and increased fat cell size, insulin-resistant diabetes and dyslipidaemia associated with decreased adiponectin and increased TNF $\alpha$ (Hotamisligil et al., 1993). Resistin, an adipokine which promotes insulin resistance in mice (Steppan et al., 2001) was reduced. Notably, adipose levels of the glucocorticoid-inducible (McGehee et al., 1993) vasoactive propeptide angiotensinogen were highly elevated in aP2-11 $\beta$-HSD1 adipose and appeared to drive the hypertension of the model (Masuzaki et al., 2003). Finally, despite hyperleptinameia, the animals exhibited hyperphagia, indicating hypothalamic leptin resistance. Thus by increasing adipose glucocorticoid reactivation to levels seen in human metabolic syndrome, the aP2-11 $\beta$-HSD1 model appeared to show that altered adipose tissue glucocorticoid metabolism could be the primary driver of many features of this disease.

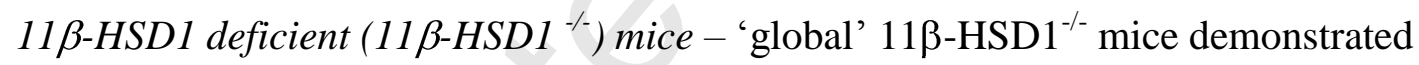
that $11 \beta$-HSD1 was the only enzyme capable of reactivating inert 11-ketosteroids to active glucocorticoids (Kotelevtsev et al., 1997). These studies clearly demonstrated the role of the enzyme in the (hepatic) stress response to fasting, and furthermore showed that $11 \beta-\mathrm{HSD}^{-{ }^{--}}$mice resisted high fat diet-induced hyperglycaemia (Kotelevtsev et al., 1997). To investigate the potential of $11 \beta$-HSD1 deficiency as a model of anti-obesity therapy, the transgene was back-crossed on to an obesity-prone $(\mathrm{C} 57 \mathrm{~B} 1 / 6 \mathrm{~J})$ genetic background. C57B1/6J-11 $\beta-\mathrm{HSD}^{-/-}$mice gained significantly less weight than controls when chronically fed a high fat diet due to an enhanced metabolic rate. This occurred despite an unexpected transient hyperphagia (Morton et al., 2004b, Densmore et al., 2006). Moreover, in an inverse manner to ap2-11 $\beta$-HSD1 mice, $11 \beta-\mathrm{HSD}^{-/-}$mice preferentially gained adipose tissue in peripheral depots rather than in the visceral depot. $11 \beta-\mathrm{HSD}^{-/-}$mice had higher adipose PPAR $\gamma$ mRNA levels in their fat. Since PPAR $\gamma$ ligands cause insulin sensitisation and fat 
redistribution to the periphery (Kelly et al., 1999, Sewter et al., 2002), a mechanism for the beneficial fat redistribution was suggested, on the assumption that increased circulating free fatty acids during high fat feeding were acting as endogenous ligands for the PPAR $\gamma$ receptors (Xu et al., 1999). In agreement with both increased PPAR $\gamma$ and reduced glucocorticoid action, insulin sensitisation is evident in isolated primary $11 \beta-\mathrm{HSD}^{-/}$adipocytes which showed increased basal and insulin-stimulated glucose uptake. Further, Uncoupling protein-2 levels were higher in $11 \beta-\mathrm{HSD}^{-{ }^{-}}$adipose, consistent with glucocorticoid (Xu et al., 1999) and PPAR $\gamma$ regulation (Digby et al., 2000). Higher PPAR- $\gamma$-responsive uncoupling protein (UCP)-2 expression in the $11 \beta-\mathrm{HSD}^{-/-}$adipose may drive increased energy dissipation within the adipocytes (Morton et al., 2004b). A related increase in adipose lipid oxidation (CPT-1 activity) was subsequently shown by others using $11 \beta$-HSD1 inhibitors, along with specifically reduced visceral fat mass and cell size (Berthiaume et al., 2007a). 11 $\beta-H S D 1^{-/-}$mice also exhibited reduced leptin, (perhaps a cause of the transiently increased food intake; Morton et al., 2004b, Densmore et al., 2006), resistin and TNF $\alpha$ mRNA levels in adipose whereas adiponectin was increased, compatible with an adipose-mediated, insulin-sensitised phenotype. $11 \beta-\mathrm{HSD}^{-/-}$mice showed improved glucose tolerance and lower fasting free fatty acids, indirectly confirming adipose insulin sensitisation. Thus $11 \beta$-HSD1 gene deficiency is associated with a number of improvements of adipose function that highlight again the importance of adipose 11 $\beta$-HSD1 in the development of metabolic disease with obesity (Figure 2).

Adipose 11 $\beta$-HSD2 Overexpressing Mice - Ectopic expression of the glucocorticoidinactivating $11 \beta$-HSD2 isozyme in adipose tissue was achieved using the aP2 promoter (Kershaw et al., 2005). 11 $\beta$-HSD2 expression levels were similar to that found in the kidney, where $11 \beta$-HSD2 performs its physiological role to exclude corticosterone from the high affinity mineralocorticoid receptor. In close parallel with $11 \beta-\mathrm{HSD}^{-/-}$mice, aP2-11 $\beta$-HSD2 mice resisted high fat diet-induced obesity and insulin resistance in association with decreased leptin and resistin, but increased adiponectin, PPAR $\gamma$ and uncoupling protein-2 expression in fat tissues. The model reinforces the concept that reducing adipose levels of active glucocorticoid promotes a metabolic disease-resistant phenotype (Figure 2). 


\section{Other important sites of 11 $\beta$-HSD1 expression.}

Liver - Glucocorticoids impair hepatic insulin sensitivity and promote hepatic glucose production, in part by direct action on the PEPCK gene (Barthel and Schmoll 2003, Chakravarty et al., 2005). This drives hyperglycaemia during insulin resistant states such as diabetes. The liver is also the organ with the highest 11 $\beta$-HSD1 expression (Tannin et al., 1991), at least 10 times higher than adipose. Inhibition of 11 $\beta$-HSD1 by carbenoxolone improved insulin sensitivity in humans and rats (Walker et al., 1995, Livingstone et al., 2000). Early rodent studies suggested that carbenoxolone had poor efficacy within adipose issue (Livingstone et al., 2000) and as such the antidiabetic effects of $11 \beta$-HSD1 inhibition were ascribed largely to liver inhibition. This notion was strengthened by more recent studies using specific $11 \beta$-HSD-1 inhibitors which reduced hyperglycaemia in diabetic mice (Alberts et al., 2002). Human adipose tissue microdialysis (Sandeep et al., 2005, Tomlinson et al., 2007) have shown some efificay of carbenoxolone in adipose. Further, carbenoxolone can reduce liver triglyceride production, improve glucose tolerance and ameliorate atherogenesis with combined inhibition of liver and adipose $11 \beta-$ HSD1 in dyslipidaemic or high fat dietinduced obese rodents (Nuotio-Antar, 2007, Taylor et al., 2008).

Drug efficacy aside, hepatic $11 \beta-H S D 1$ is actually reduced in obesity (Stewart et al., 1999, Livingstone et al., 2000, Rask et al., 2001, Morton and Seckl 2008), suggesting that it is not the primary driver of the disease process. Nevertheless, since aP2-11 $\beta$ HSD1 mice exhibited elevated portal corticosterone levels, this suggested increased glucocorticoid delivery to the liver may occur, at least in rodent obesity. To address whether excess hepatic glucocorticoid (or indeed elevated hepatic $11 \beta$-HSD1 per se) could cause the metabolic syndrome, a liver-specific $11 \beta$-HSD1 overexpressing line was generated using the apoE promoter (Paterson et al., 2004). ApoE-11 $\beta$-HSD1 mice showed modest insulin resistance and hypertriglyceridaemia and were

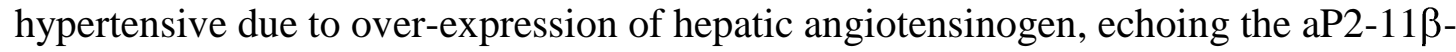
HSD1 hypertensive mechanism. Curiously, the major effects of hepatic 11 $\beta$-HSD1 overexpression were on lipid synthesis and transport enzymes rather than glucose homeostasis (Paterson et al., 2004), but do highlight the important role of glucocorticoids in regulation of lipid homeostasis (Brindley, 1995, Dolinsky et al., 2004). An attenuated metabolic syndrome driven by high liver $11 \beta-H S D 1$ in mice 
indicates the enzyme makes an important contribution to metabolic disease in other rodent models (Morton et al., 2005, Liu et al., 2005) and indeed indicates a potential therapeutic avenue in patients with a liver selective increase in $11 \beta$-HSD1 such as myotonic dystrophy (Johansson et al., 2001). In contrast, 11 $\beta-\mathrm{HSD}^{-/-}$mice exhibited increased expression of PPAR $\alpha$ and downstream genes linked to $\beta$-oxidation such as CPT-1 in liver (Morton et al., 2001). Increased liver fatty acid $\beta$-oxidation after $11 \beta$ HSD1 inhibitor treatment has recently been confirmed by others (Berthiaume et al., 2007b). These changes were associated with an improved lipid and lipoprotein profile in $11 \beta-\mathrm{HSD}^{-/-}$mice, including increased HDL cholesterol and reduced VLDL triglyceride levels (Morton et al., 2001, Morton et al., 2004a).

Skeletal muscle - Glucocorticoids potently induce insulin resistance in skeletal muscle through the glucocorticoid receptor (Dimitriadis et al., 1997, Smith and Muscat 2005). Expression of 11 $\beta$-HSD1 is held to be low in muscle tissue of mice (Itoh et al., 2004, Morton et al., 2004). Further, human 11 $\beta$-HSD1 mRNA levels did not correlate with any metabolic parameters, unlike adipose $11 \beta$-HSD1 in obese PIMA Indians (Nair et al, 2004). However, a number of studies have highlighted the importance of skeletal muscle as a potential site of activity of the enzyme in humans (Whorwood et al., 2001, Abdallah et al., 2005, Jang et al. 2006, 2007) which may reflect a species difference. $11 \beta$-HSD1 activity appears to be lower in muscle biopsies of diabetic than control subjects, but is induced following dexamethasone administration (Jang et al., 2007). Further, 11 $\beta$-HSD1 activity is higher in myotubes derived from diabetic or insulin resistant subjects (Whorwood et al., 2001, Abdallah et al., 2005). Skeletal muscle $11 \beta$-HSD1 is also induced after the stress of elective surgery (Obeyesekere et al., 2008). The significance of skeletal muscle 11 $\beta$-HSD1 requires clarification, but represents a clearly important target tissue given the role of glucocorticoids in skeletal muscle insulin resistance.

Pancreas - Chronic glucocorticoid action can directly suppress insulin transcription and secretion (Delaunay et al., 1997), which is often masked by the compensatory hyperinsulinaemia that results from the induction of peripheral insulin resistance by glucocorticoids. $11 \beta$-HSD1 is expressed in pancreatic islets and its expression is higher in islets from obese rodents where inhibition with carbenoxolone or selective 11ß-HSD1 inhibitors (Davani et al., 2000, Ortsater et al., 2005) alleviates the 11- 
ketoglucocorticoid-mediated suppression of insulin secretion in these models. An intriguing new finding suggests that $11 \beta$-HSD1 is expressed most highly in the glucagon secreting alpha cells, where the authors suggested the effects on insulin secretion might occur through a paracrine modulation of insulin secretion by this hormone (Swali et al., 2008). Again more work is required to dissect the functional role of glucocorticoids and 11 $\beta$-HSD1 in the endocrine pancreas. For example, in contrast to earlier studies, a recent study showed glucocorticoids directly increased islet insulin secretion through an anit-inflammatory action (Hult et al., 2008). Dose and duration of glucocorticoid exposure will be an important determinant of the direct islet effects, as will the potential for alternate substrate metabolism (Schweizer et al., 2004, Wamil et al., 2008). Preliminary data indicate that islet insulin secretion is appropriately low from high fat fed $11 \beta-\mathrm{HSD}^{-/-}$mice (S Turban, JR Seckl and NM Morton, unpublished observations), but that is to be expected within the context of their insulin-sensitised phenotype. Work is ongoing in the Morton laboratory to characterise the phenotype of a $\beta$-cell specific $11 \beta$-HSD1 overexpressing transgenic mouse created to more directly test these hypotheses.

Blood vessels and the vascular wall - Glucocorticoids are angiostatic and $11 \beta-\mathrm{HSD}^{-/-}$ mice show increased angiogenic responses, which contributes to their improved recovery after myocardial infarction in vivo (Small et al., 2005). Angiogenesis is a key determinant of adipose tissue expansion during obesity and inhibition of this process prevents obesity (Rupnick et al., 2002, Lijnen et al., 2008). If the angiostatic glucocorticoid effect translates to adipose tissue, 11 $\beta$-HSD1 deficiency would potentially promote a more robust angiogenic response to the rapid expansion of adipose tissue with obesity in vivo, improving vascularisation and reducing the downstream inflammatory consequences (Figure 2). A caveat to these salutary effects, however, would be a potential for an undesirable increase in angiogenesis in disease states such as cancer and diabetic retinopathy of which there is increased risk with

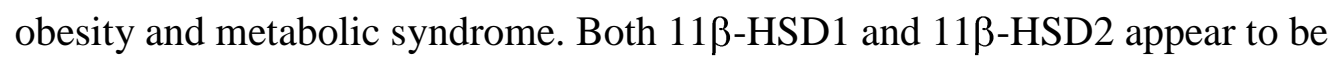
expressed in human endothelial cells, and modulate inducible nitric oxide synthase (iNOS) activity (Liu et al., 2008). The story in rodents is less clear, but suggests that expression of $11 \beta$-HSD isoforms may be both species and anatomical (perhaps fat depot) site-specific (Hadoke et al., 2006). 11 $\beta$-HSD1 is expressed in smooth muscle cells (Hadoke et al., 2006), and as described below, in macropahges. All three cell 
types are critical for the formation of atherosclerotic plaques. With the reported reduction in atherosclerotic lesions in dyslipidaemic apoE null mice of $84 \%$ using a selective 11 $\beta$-HSD1 inhibitor (Hermanowkski-Vosatka et al., 2005), the search is on to define whether endothelial cells, vascular smooth muscle, macrophages or rather the improvement in liver lipid metabolism and altered release of atherogenic adipokines (Lau et al., 2005) from adipose accounts for the largest proportion of this remarkable protective effect.

Macrophages - High dose glucocorticoids potently dampen pro-inflammatory cytokine signalling by suppressing nuclear transcription factor (NF)- $\mathrm{KB}$ and activator protein (AP)-1 signalling cascades (Riechardt and Schutz 1998). Furthermore, glucocorticoids confer phagocytic capacity to macrophages, which ingest and process apoptotic leukocytes (neutrophils) at the sites of inflammation (Giles et al., 2001). As noted above, adipose tissue becomes infiltrated with pro-inflammatory macrophages during obesity. The LPS-TLR system is activated in adipocytes and macrophages through high free fatty acid levels in obesity (Lin et al., 2000, Shi et al., 2007, Song et al., 2007, Nguyen et al., 2007). 11 $\beta$-HSD1 is induced upon macrophage activation by stimuli such as lipoplysaccahride (LPS) in human monocytes and mouse macrophages (Thieringer et al., 2001, Gilmour et al., 2006, Ishii et al., 2006). The enzyme is also increased by proinflammatory cytokines in fibroblasts (Hardy et al., 2006, Hardy et al., 2008) and smooth muscle cells (Cai et al., 2000), by cytokines such as TNF- $\alpha$ and IL-1 $\beta$ where it may modulate inflammatory processes such as rheumatoid arthritis and atherosclerosis. From studies investigating the effects of glucocorticoids (Giles et al., 2001) on macrophage function in classical inflammatory models, the potential expression of $11 \beta-H S D 1$ within adipose macrophages thus becomes highly relevant to the adipose inflammation story. 11 $\beta$-HSD1 augments glucocorticoid-induced macrophage phagocytosis (Giles et al., 2001) thus promoting resolution of inflammatory processes (Gilmour et al, 2006). The latter concept is clear within the context of classical (acute/severe) inflammatory paradigms (Thieringer et al., 2001, Gilmour et al., 2006, Ishii et al., 2006, Chapman et al., 2008). It might then be expected that obesity would lead to increased activation and expression of adipose macrophage 11 $\beta$-HSD1, which may help to resolve adipose inflammation. However, when $11 \beta-\mathrm{HSD}^{-/-}$mice are challenged with LPS-mediated endotoxaemia, they exhibit exaggerated systemic and (splenic) macrophage inflammatory responses 
through the TGF $\beta$-induced SHIP-1, NF- $\kappa \mathrm{B}$ and MAPK intracellular signalling cascades (Zhang and Daynes, 2007). This was accompanied by an increased secretion of cytokines, particularly the glucocorticoid suppressible IL-6 (Gilmour et al., 2006) from the $11 \beta-\mathrm{HSD}^{-/-}$macrophages (Zhang and Daynes 2007). The authors attributed this macrophage hyperresponsiveness to the subtly higher in vivo glucocorticoid levels driving an altered myeloid differentiation process (control and $11 \beta-\mathrm{HSD}^{-1}$ macrophages had similar LPS responses when differentiated in vitro). In contrast, 11 $\beta$-HSD1 inhibition, perhaps counter intuitively, suppressed inflammatory cytokine release in J774.1 macrophage cells in vitro (Ishii et al., 2006), adding to the complex role of $11 \beta-H S D 1$ in the regulation of inflammatory responses. Currently our understanding of this process relies on acute/pharmacological inflammatory stimuli often in vitro, making the outcome for $11 \beta$-HSD1 inhibition in adipose tissue macrophages where inflammation is low grade and glucocorticoid levels vary over the physiological range hard to predict. Nevertheless, they do suggest macrophage $11 \beta$ HSD1 might be a key determinant of inflammatory processes within the fat during obesity. Further studies are under way to fully characterise the phenotype of $11 \beta$ $\mathrm{HSD}^{-{ }^{-}}$adipose tissue macrophages, but preliminary data suggest a reduced infiltration of adipose macrophages, consistent with the lower adipose TNF- $\alpha$ (Morton et al., 2004b; most of which likely derives from the adipose macrophages), and metabolic protection seen in the model (J Battle, JR Seckl, NM Morton unpublished observations).

Lymphocytes and dendritic cells - With the recent discovery that $\mathrm{T}$ cells of the adaptive immune system are involved in coordinating the early and chronic inflammatory events in adipose tissue during obesity (Wu et al., 2007, Rausch et al., 2008), it is also of note that T lymphocytes express $11 \beta$-HSD1, and this increases as the cells become polarised into Th1 and Th2 subtypes (Zhang et al., 2005). B cells also express 11ß-HSD1 (Zhang et al., 2005) although their role in adipose inflammation is unclear. Dendritic cells (bone marrow derived) are also implicated in the infiltration of, and inflammation within, adipose tissue in obesity (Nguyen et al., 2007). This cell type, at least as derived after extensive culture and a positive selection process in vitro, also expressed 11ß-HSD1 (Zhang et al., 2005). 
In summary, a number of other key inflammatory and vascular cells within the adipose tissue have the potential to express $11 \beta$-HSD1 and this may impact upon adipose (and other relevant target tissues) during the chronic low grade inflammation in obesity. However, this remains to be conclusively demonstrated in primary cells derived from the fat where a number of these important cells types are found (Zeyda et al., 2007).

\section{1 $\beta$-HSD1 Inhibitors as Therapeutics.}

To date, pharmacological intervention with $11 \beta$-HSD1 inhibition in vivo has shown the full range of protective metabolic, anti-obesity, anti-inflammatory and antiatherogenic effects with a growing body of evidence for beneficial effects in man (Walker et al., 1995, Andrews et al., 2003, Hermanowski-Vosatka, et al., 2005, Sandeep et al., 2005, Tomlinson et al., 2007, see Hughes et al, 2008 for an extensive review).

Many pieces to the therapeutic jigsaw remain to be placed in terms of making $11 \beta$ HSD1 the next potential major obesity and metabolic syndrome pharmacotherapy as other prime candidates fall by the wayside (Christensen et al., 2007, Singh and Locke, 2008). The role and effect of $11 \beta$-HSD1 inhibition of macrophage function in adipose and atherosclerotic lesions is unclear. Equally, lymphocyte and other immunocytes express 11 $\beta$-HSD1 (Daynes et al., 2005). Determining the role of 11 $\beta$-HSD1 in these cells is critical to the application of inhibitors and may present unwanted adverse effects during acute infection or acute- or severe/chronic- inflammation (Chapman et al., 2008). Clarification of the potentially beneficial effects on (adipose and myocardial) angiogenesis will be needed. Central effects of 11 $\beta$-HSD1 on appetite (Densmore et al., 2006) have been observed and some (Hermanowski-Vosatka 2005, Gu et al., 2005, Wang et al., 2006), but not all inhibitor studies report an effect on food intake. Since this appears to be weight loss, this could be a positive therapeutic effect. The role and direct effects of $11 \beta-H S D 1$ in subpopulations of the endocrine pancreas during the inflammatory processes of diabetes (Donath et al., 2005) and in skeletal muscle with insulin resistance also require clarification. Finally, it is important to note that with inhibition of cortisol regeneration as a therapeutic strategy, care must be taken to consider effects in cells also expressing MR and low levels of the cortisol-inactivating $11 \beta$-HSD2 enzyme, potentially even the adipocytes and 
macrophages (Hirata et al., 2009, Gilmour et al., 2006). Notably, cortisol cannot distinguish between MR and GR whereas the potent anti-inflammatory steroid dexamethasone (note: 11keto-dexamethosone activates GR comparably) despite binding MR with higher affinity than GR, does not transactivate MR-mediated gene transcription (Rebuffat et al., 2004). The complexities of 11 $\beta$-HSD1 inhibition as a potential therapeutic strategy to reduce cortisol levels in metabolic disease in a coassociated inflammatory state where dexamethasone (or indeed other steroid analogues such as prednisolone) is indicated, for example, will require careful validation within the disease- and tissue-specific context.

\section{Summary and persepctives.}

Loss of glucocorticoid reactivation by $11 \beta-$ HSD1 reduces formation of new fat cells, improves insulin sensitivity, increases fat oxidation in liver and adipocytes, promotes a favourable redistribution of fat, reduces cellular stress, favourably alters adipokine secretion from adipocytes and reduces infiltration of adipose macrophages in obesity. There may potentially be beneficial effects of reduced glucocorticoid spillover (likely only in subcutaneous fat in humans) on local adipose macrophages, other immunocytes and the local vasculature. Some of these effects may be mediated by altered expression of 11 $\beta$-HSD1 within those cell types in an intracrine manner. To date these benefits appear to offset any potential detrimental effects, such as those predicted by the impaired inflammation pro-resolution effect in $11 \beta-\mathrm{HSD}^{-/-}$ macrophages (Gilmour et al., 2006). Ongoing studies using cell-specific transgenic manipulation and ever increasingly potent, selective, and tissue-targeted inhibitors (eg CNS permeable for hypothalamic appetite and cognitive applications) are helping to elucidate the complex biology of this intracellular signalling system and its potential in combating the most devastating and costly disease burden of the modern era. 


\section{References}

Abdallah BM, Beck-Nielsen H, Gaster M. 2005.Increased expression of 11 betahydroxysteroid dehydrogenase type 1 in type 2 diabetic myotubes. Eur J Clin Invest. 35(10):627-34.

Ailhaud G, Amri E, Bardon S, Barcellini-Couget S, Bertrand B, Catalioto RM, Dani C, Doglio A, Forest C, Gaillard D, et al. 1991. Growth and differentiation of regional adipose tissue: molecular and hormonal mechanisms. Int J Obes. 15 Suppl 2:87-90.

Alberts P, Engblom L, Edling N, Forsgren M, Klingstrom G, Larsson C, Ronquist-Nii Y, Ohman B, Abrahmsen L 2002. Selective inhibition of 11 beta-hydroxysteroid dehydrogenase type 1 decreases blood glucose concentrations in hyperglycaemic mice. Diabetologia 45(11): 1528-1532.A

Andrew, R, Phillips, DIW and Walker, BR.1998. Obesity and gender influence cortisol secretion and metabolism in man. J Clin Endocrinol Metab 83: 1806-1809.

Andrews RC, Rooyackers O, Walker BR. 2003 Effects of the 11 beta-hydroxysteroid dehydrogenase inhibitor carbenoxolone on insulin sensitivity in men with type 2 diabetes. J Clin Endocrinol Metab. 88(1):285-91.

Arai N, Masuzaki H, Tanaka T, Ishii T, Yasue S, Kobayashi N, Tomita T, Noguchi M, Kusakabe T, Fujikura J, Ebihara K, Hirata M, Hosoda K, Hayashi T, Sawai H, Minokoshi Y, Nakao K. 2007. Ceramide and adenosine 5'-monophosphate-activated protein kinase are two novel regulators of 11beta-hydroxysteroid dehydrogenase type 1 expression and activity in cultured preadipocytes. Endocrinology 148(11):5268-77. Atanasov, AG, Nashev, LG, Schweizer, RAS, Frick, C and Odermatt, A. 2004. Hexose-6-phosphate dehydrogenase determines the reaction direction of 11 betahydroxysteroid dehydrogenase type 1 as an oxoreductase. Febs Letters 571(1-3): 129133.

Atsumi T, Cho YR, Leng L, McDonald C, Yu T, Danton C, Hong EG, Mitchell RA, Metz C, Niwa H, Takeuchi J, Onodera S, Umino T, Yoshioka N, Koike T, Kim JK, Bucala R. 2007. The proinflammatory cytokine macrophage migration inhibitory factor regulates glucose metabolism during systemic inflammation. J Immunol. Oct 15;179(8):5399-406.

Barthel A, Schmoll D. 2003. Novel concepts in insulin regulation of hepatic gluconeogenesis. Am J Physiol Endocrinol Metab. Oct;285(4):E685-92. Basu R, Basu A, Grudzien M, Jung P, Jacobson P, Johnson M, Singh R, Sarr M, Rizza R. 2008. The Liver is the Site of Splanchnic Cortisol Production in Obese Nondiabetic Humans. Diabetes. Oct 13.

Basu R, Edgerton DS, Singh RJ, Cherrington A, Rizza RA. 2006. Splanchnic Cortisol Production in Dogs Occurs Primarily in the Liver: Evidence for Substantial Hepatic Specific 11 \{beta\} Hydroxysteroid Dehydrogenase Type 1 Activity. Diabetes 55(11): 3013-9.

Berg AH, Combs TP, Du X, Brownlee M, Scherer PE 2001. The adipocyte-secreted protein Acrp30 enhances hepatic insulin action. Nat Med 7:947-953.

Berthiaume M, Laplante M, Festuccia W, Gélinas Y, Poulin S, Lalonde J, Joanisse DR, Thieringer R, Deshaies Y. 2007a. Depot-specific modulation of rat intraabdominal adipose tissue lipid metabolism by pharmacological inhibition of 11beta-hydroxysteroid dehydrogenase type 1. Endocrinology. 148(5):2391-7. Berthiaume M, Laplante M, Festuccia WT, Cianflone K, Turcotte LP, Joanisse DR, Olivecrona G, Thieringer R, Deshaies Y. 2007b. 11beta-HSD1 inhibition improves triglyceridemia through reduced liver VLDL secretion and partitions lipids toward oxidative tissues. Am J Physiol Endocrinol Metab. 293(4):E1045-52.

Björntorp P, Rosmond R. 2000. Obesity and cortisol. Nutrition. 16(10):924-36. 
Boruk M, Savory JG, Hache RJ. 1998. AF-2-dependent potentiation of CCAAT enhancer binding protein beta-mediated transcriptional activation by glucocorticoid receptor. Mol Endocrinol 12: 1749-1763.

Brindley DN.Role of glucocorticoids and fatty acids in the impairment of lipid metabolism observed in the metabolic syndrome. Int J Obes Relat Metab Disord. 1995 Bujalska IJ, Walker EA, Tomlinson JW, Hewison M, Stewart PM. 2002.11Betahydroxysteroid dehydrogenase type 1 in differentiating omental human preadipocytes: from de-activation to generation of cortisol. Endocr Res. 28(4):449-61.

Bujalska, I, Kumar, S and Stewart, PM 1997. Does central obesity reflect "Cushing's disease of the omentum". Lancet 349: 1210-1213.

Cai TQ, Wong B, Mundt SS, Thieringer R, Wright SD, Hermanowski-Vosatka A. 2001. Induction of 11 beta-hydroxysteroid dehydrogenase type 1 but not -2 in human aortic smooth muscle cells by inflammatory stimuli. J Steroid Biochem Mol Biol. 77(2-3):117-22.

Chakravarty K, Cassuto H, Reshef L, Hanson RW. 2005. Factors that control the tissue-specific transcription of the gene for phosphoenolpyruvate carboxykinase-C. Crit Rev Biochem Mol Biol. 40(3):129-54.

Chapman KE, Coutinho AE, Gray M, Gilmour JS, Savill JS, Seckl JR. 2008. The role and regulation of 11 beta-hydroxysteroid dehydrogenase type 1 in the inflammatory response. Mol Cell Endocrinol. (epub ahead of print).

Christ-Crain M, Kola B, Lolli F, Fekete C, Seboek D, Wittmann G, Feltrin D, Igreja SC, Ajodha S, Harvey-White J, Kunos G, Müller B, Pralong F, Aubert G, Arnaldi G, Giacchetti G, Boscaro M, Grossman AB, Korbonits M. 2008. AMP-activated protein kinase mediates glucocorticoid-induced metabolic changes: a novel mechanism in Cushing's syndrome. FASEB J. 22(6):1672-83.

Christensen R, Kristensen PK, Bartels EM, Bliddal H, Astrup A. 2007. Efficacy and safety of the weight-loss drug rimonabant: a meta-analysis of randomised trials. Lancet. 370(9600):1706-13.

Cinti S, Mitchell G, Barbatelli G, Murano I, Ceresi E, Faloia E, Wang S, Fortier M, Greenberg AS, Obin MS. 2005. Adipocyte death defines macrophage localization and function in adipose tissue of obese mice and humans. J Lipid Res. 46(11):2347-55. Dallman MF, la Fleur SE, Pecoraro NC, Gomez F, Houshyar H, Akana SF. 2004. 2004.Minireview: glucocorticoids--food intake, abdominal obesity, and wealthy nations Endocrinology. 145(6):2633-8.

Davani B, Khan A, Hult M, Mårtensson E, Okret S, Efendic S, Jörnvall H, Oppermann UC. 2000. Type 111 beta -hydroxysteroid dehydrogenase mediates glucocorticoid activation and insulin release in pancreatic islets. $\mathrm{J}$ Biol Chem. 275(45):34841-4.

De Sousa Peixoto RA, Turban S, Battle JH, Chapman KE, Seckl JR, Morton NM. 2008. Preadipocyte 11beta-hydroxysteroid dehydrogenase type 1 is a keto-reductase and contributes to diet-induced visceral obesity in vivo. Endocrinology 149(4):18618 .

Delaunay F, Khan A, Cintra A, Davani B, Ling ZC, Andersson A, Ostenson CG, Gustafsson J, Efendic S, Okret S. 1997. Pancreatic beta cells are important targets for the diabetogenic effects of glucocorticoids. J Clin Invest. 15;100(8):2094-8.

Densmore VS, Morton NM, Mullins JJ, Seckl JR. 2006. 11 beta-hydroxysteroid dehydrogenase type 1 induction in the arcuate nucleus by high-fat feeding: A novel constraint to hyperphagia? Endocrinology. 147(9):4486-95. 
Desbriere R, Vuaroqueaux V, Achard V, Boullu-Ciocca S, Labuhn M, Dutour A, Grino M. 2006.11beta-hydroxysteroid dehydrogenase type 1 mRNA is increased in both visceral and subcutaneous adipose tissue of obese patients. Obesity (Silver Spring). 14(5):794-8.

Digby, JE, Crowley, VEF, Sewter, CP, Whitehead, JP, Prins, JB and O'Rahilly, S 2000 Depot-related and thiazolidinedione-responsive expression of uncoupling protein 2 (UCP2) in human adipocytes. Int J Obes; 24(5): 585-592.

Dimitriadis G, Leighton B, Parry-Billings M, Sasson S, Young M, Krause U, Bevan S, Piva T, Wegener G, Newsholme EA. 1997. Effects of glucocorticoid excess on the sensitivity of glucose transport and metabolism to insulin in rat skeletal muscle. Biochem J. 321 (Pt 3):707-12.

Dolinsky VW, Douglas DN, Lehner R, Vance DE. 2004 Regulation of the enzymes of hepatic microsomal triacylglycerol lipolysis and re-esterification by the glucocorticoid dexamethasone. Biochem J. 378:967-74.

Donath MY, Størling J, Berchtold LA, Billestrup N, Mandrup-Poulsen T. 2008. Cytokines and beta-cell biology: from concept to clinical translation. Endocr Rev. 29(3):334-50.

Engeli, S, Bohnke, J, Feldpausch, M, Gorzelniak, K, Heintze, U, Janke, J, Luft FC, Sharma AM. 2004. Regulation of 11 beta-HSD genes in human adipose tissue: Influence of central obesity and weight loss. Obesity Research 12(1): 9-17.

Fasshauer M, Klein J, Kralisch S, Klier M, Lossner U, Bluher M, Paschke R. 2004. Serum amyloid A3 expression is stimulated by dexamethasone and interleukin-6 in 3T3-L1 adipocytes. J Endocrinol. 183(3):561-7.

Fasshauer M, Klein J, Lossner U, Paschke R. 2003. Interleukin (IL)-6 mRNA expression is stimulated by insulin, isoproterenol, tumour necrosis factor alpha, growth hormone, and IL-6 in 3T3-L1 adipocytes. Horm Metab Res. 35(3):147-52.

Fasshauer M, Kralisch S, Klier M, Lossner U, Bluher M, Klein J, Paschke R. 2003b. Adiponectin gene expression and secretion is inhibited by interleukin-6 in 3T3-L1 adipocytes. Biochem Biophys Res Commun. 301(4):1045-50.

Gaillard D, Wabitsch M, Pipy B, Négrel R. 1991. Control of terminal differentiation of adipose precursor cells by glucocorticoids. J Lipid Res. 1991 32(4):569-79.

Giles KM, Ross K, Rossi AG, Hotchin NA, Haslett C, Dransfield I. 2001.

Glucocorticoid augmentation of macrophage capacity for phagocytosis of apoptotic cells is associated with reduced p130Cas expression, loss of paxillin/pyk2 phosphorylation, and high levels of active Rac. J Immunol. 167(2):976-86.

Gilmour, J. S., A. E. Coutinho, Cailhier, JF, Man TY, Clay M, Thomas G, Harris HJ, Mullins JJ, Seckl JR, Savill JS, Chapman KE 2006. Local amplification of glucocorticoids by 11 beta-hydroxysteroid dehydrogenase type 1 promotes macrophage phagocytosis of apoptotic leukocytes. J Immunol. 176 (12): 7605-11. Goedecke, JH, Wake, DJ, Levitt, NS, Lambert, EV, Collins, MR, Morton, NM, Andrew, R, Seckl, JR and Walker, BR. 2006. Glucocorticoid metabolism within superficial subcutaneous rather than visceral adipose tisuue is a ssociated with features of the metabolic syndrome in South African women. Clin Endocrinol 65: 8187.

Gu X, Dragovic J, Koo GC, Koprak SL, LeGrand C, Mundt SS, Shah K, Springer MS, Tan EY, Thieringer R, Hermanowski-Vosatka A, Zokian HJ, Balkovec JM, Waddell ST. 2005. Discovery of 4-heteroarylbicyclo[2.2.2]octyltriazoles as potent and selective inhibitors of 11beta-HSD1: novel therapeutic agents for the treatment of metabolic syndrome. Bioorg Med Chem Lett. 15(23):5266-9. 
Guo C, Ricchiuti V, Lian BQ, Yao TM, Coutinho P, Romero JR, Li J, Williams GH, Adler GK. 2008. Mineralocorticoid receptor blockade reverses obesity-related changes in expression of adiponectin, peroxisome proliferator-activated receptorgamma, and proinflammatory adipokines. Circulation. 117(17):2253-61.

Hadoke PW, Macdonald L, Logie JJ, Small GR, Dover AR, Walker BR. 2006. Intravascular glucocorticoid metabolism as a modulator of vascular structure and function. Cell Mol Life Sci. 63(5):565-78.

Hardy R, Rabbitt EH, Filer A, Emery P, Hewison M, Stewart PM, Gittoes NJ, Buckley CD, Raza K, Cooper MS. 2008. Local and systemic glucocorticoid metabolism in inflammatory arthritis. Ann Rheum Dis. 67(9):1204-10.

Hardy RS, Filer A, Cooper MS, Parsonage G, Raza K, Hardie DL, Rabbitt EH, Stewart PM, Buckley CD, Hewison M. 2008. Differential expression, function and response to inflammatory stimuli of 11 beta-hydroxysteroid dehydrogenase type 1 in human fibroblasts: a mechanism for tissue-specific regulation of inflammation. Ann Rheum Dis. 67(9):1204-10.

Hermanowski-Vosatka A, Balkovec JM, Cheng K, Chen HY, Hernandez M, Koo GC, Le Grand CB, Li Z, Metzger JM, Mundt SS, Noonan H, Nunes CN, Olson SH, Pikounis B, Ren N, Robertson N, Schaeffer JM, Shah K, Springer MS, Strack AM, Strowski M, Wu K, Wu T, Xiao J, Zhang BB, Wright SD, Thieringer R. 11betaHSD1 inhibition ameliorates metabolic syndrome and prevents progression of atherosclerosis in mice. J Exp Med. 2005 202(4):517-27.

Hirata A, Maeda N, Hiuge A, Hibuse T, Fujita K, Okada T, Kihara S, Funahashi T, Shimomura I. Blockade of mineralocorticoid receptor reverses adipocyte dysfunction and insulin resistance in obese mice. Cardiovasc Res. 2009 Oct 1;84(1):164-72.

Hotamisligil GS. 2006. Inflammation and metabolic disorders. Nature.

444(7121):860-7.

Hotamisligil, G, Shargill, N and Spiegelman, BM. 1993. Adipose expression of tumor necrosis factor-alpha: direct role in obesity-linked insulin resistance. Science 259: 8791.

Hughes KA, Webster SP, Walker BR. 2008.11-Beta-hydroxysteroid dehydrogenase type 1 (11beta-HSD1) inhibitors in type 2 diabetes mellitus and obesity. Expert Opin Investig Drugs. 17(4):481-96.

Hult M, Ortsäter H, Schuster G, Graedler F, Beckers J, Adamski J, Ploner A, Jörnvall H, Bergsten P, Oppermann U. 2008. Short-term glucocorticoid treatment increases insulin secretion in islets derived from lean mice through multiple pathways and mechanisms. Mol Cell Endocrinol. Oct 15. [Epub ahead of print] Ishii T, Masuzaki H, Tanaka T, Arai N, Yasue S, Kobayashi N, Tomita T, Noguchi M, Fujikura J, Ebihara K, Hosoda K, Nakao K. 2007. Augmentation of 11 betahydroxysteroid dehydrogenase type 1 in LPS-activated J774.1 macrophages--role of 11 beta-HSD1 in pro-inflammatory properties in macrophages. FEBS Lett. 6;581(3):349-54.

Itoh E, Iida K, Kim DS, Del Rincon JP, Coschigano KT, Kopchick JJ, Thorner MO. 2004. Lack of contribution of 11 betaHSD1 and glucocorticoid action to reduced muscle mass associated with reduced growth hormone action. Growth Horm IGF Res. 14(6):462-6.

Jang C, Obeyesekere VR, Dilley RJ, Alford FP, Inder WJ. 2006.11Beta hydroxysteroid dehydrogenase type 1 is expressed and is biologically active in human skeletal muscle. Clin Endocrinol (Oxf).65(6):800-5. 
Jang C, Obeyesekere VR, Dilley RJ, Krozowski Z, Inder WJ, Alford FP. 2007. Altered activity of 11beta-hydroxysteroid dehydrogenase types 1 and 2 in skeletal muscle confers metabolic protection in subjects with type 2 diabetes. J Clin Endocrinol Metab. 92(8):3314-20.

Jensen MD. 2007. Adipose tissue metabolism -- an aspect we should not neglect? Horm Metab Res. 39(10):722-5.

Johansson, A, Andrew, R, Forsberg, H, Cederquist, K, Walker, BR and Olsson, T Glucocorticoid metabolism and adrenocortical reactivity to ACTH in myotonic dystrophy. J Clin Endocrinol Metab 2001; 86: 4276-4283.

Kannisto K, Pietiläinen KH, Ehrenborg E, Rissanen A, Kaprio J, Hamsten A, YkiJärvinen H. 2004. Overexpression of 11beta-hydroxysteroid dehydrogenase-1 in adipose tissue is associated with acquired obesity and features of insulin resistance: studies in young adult monozygotic twins. J Clin Endocrinol Metab. 89(9):4414-21. Kelly, IE, Han, TS, Walsh, K and Lean, MEJ. 1999. Effects of a thiazolidinedione compound on body fat and fat distribution of patients with type 2 diabetes. Diabetes Care 22(2): 288-293.

Kershaw, E, Morton, N, Dhillon, H, Ramage, L, Seckl, J and Flier, J. 2005.

Adipocyte-specific glucocorticoid inactivation protects against diet-induced obesity. Diabetes 54: 1023-1031.

Kissebah, AH, Vydelingum, N, Murray, R, Evans, DJ, Hartz, AJ, Kalkhoff, RK, Adams, PW. 1982. Relation of body fat distribution to metabolic complications of obesity. J Clin Endocrinol Metab; 54, 254-260.

Klöting N, Blüher M, Klöting I. 2006. The polygenetically inherited metabolic syndrome of WOKW rats is associated with insulin resistance and altered gene expression in adipose tissue. Diabetes Metab Res Rev._22(2):146-54.

Koo SH, Satoh H, Herzig S, Lee CH, Hedrick S, Kulkarni R, Evans RM, Olefsky J, Montminy M. 2004. PGC-1 promotes insulin resistance in liver through PPAR-alphadependent induction of TRB-3. Nat Med. 10(5):530-4.

Kotelevtsev, Y, Holmes, MC, Burchell, A, Houston, PM, Schmoll, D, Jamieson, PM, Best, R Brown, R, Edwards, CR Seckl, JR Mullins, JJ. 1997. 11ß-hydroxysteroid dehydrogenase type 1 knockout mice show attenuated glucocorticoid inducible responses and resist hyperglycaemia on obesity or stress. Proc Natl Acad Sci USA 94: 14924-14929.

Lau DC, Dhillon B, Yan H, Szmitko PE, Verma S. 2005. Adipokines: molecular links between obesity and atheroslcerosis. Am J Physiol Heart Circ Physiol. 288(5):H203141.

Lavery GG, Walker EA, Draper N, Jeyasuria P, Marcos J, Shackleton CH, Parker KL, White PC, Stewart PM. 2006. Hexose-6-phosphate dehydrogenase knock-out mice lack 11 beta-hydroxysteroid dehydrogenase type 1-mediated glucocorticoid generation. J Biol Chem. 281(10):6546-5144, 45.

Lee MJ, Fried SK, Mundt SS, Wang Y, Sullivan S, Stefanni A, Daugherty BL, Hermanowski-Vosatka A. 2008. Depot-specific regulation of the conversion of cortisone to cortisol in human adipose tissue. Obesity (Silver Spring) 16(6):1178-85.

Lijnen HR. 2008. Angiogenesis and obesity. Cardiovasc Res. 78(2):286-93.

Lin Y, Lee H, Berg AH, Lisanti MP, Shapiro L, Scherer PE. 2000. The lipopolysaccharide-activated toll-like receptor (TLR)-4 induces synthesis of the closely related receptor TLR-2 in adipocytes. J Biol Chem. 275(32):24255-63. 
Lin Y, Rajala MW, Berger JP, Moller DE, Barzilai N, Scherer PE. 2001.

Hyperglycemia-induced production of acute phase reactants in adipose tissue. J Biol Chem. 276(45):42077-83.

Lindsay, RS, Wake, DJ, Nair, S, Bunt, J, Livingstone, DEW, Permana, PA, Tataranni, PA and Walker, BR. 2003. Subcutaneous adipose 11 beta-hydroxysteroid dehydrogenase type 1 activity and messenger ribonucleic acid levels are associated with adiposity and insulinemia in Pima Indians and Caucasians. J Clin Endocrinol Metab. 88(6): 2738-2744.

Liu Y, Mladinov D, Pietrusz JL, Usa K, Liang M. 2008. Glucocorticoid response elements and 11 \{beta\}-hydroxysteroid dehydrogenases in the regulation of endothelial nitric oxide synthase expression. Cardiovasc Res. Sep 15. [Epub ahead of print].

Liu, YJ, Nakagawa, Y, Wang, Y, Sakurai, R, Tripathi, PV, Lutfy, K and Friedman TC. 2005. Increased glucocorticoid receptor and 11 beta-hydroxysteroid dehydrogenase type 1 expression in hepatocytes may contribute to the phenotype of type 2 diabetes in $\mathrm{db} / \mathrm{db}$ mice. Diabetes 54(1): 32-40.

Livingstone, DEW, Jones, G, Smith, K, Jamieson, PM, Andrew, R, Kenyon, CJ, and

Walker BR. 2000. Understanding the role of glucocorticoids in obesity: Tissuespecific alterations of corticosterone metabolism in obese Zucker rats. Endocrinol 141: 560-563

Marin, P, Darin, M, Amemiya, T, Andersson, B, Jern, S and Bjorntorp, P. 1992. Cortisol secretion in relation to body fat distribution in obese premenopausal women. Metabolism Clin Experimental 41: 882-888.

Masuzaki, H, Paterson, J, Shinyama, H, Morton, NM, Mullins, JJ, Seckl, JR, Flier JS. 2001. A transgenic model of visceral obesity and the Metabolic Syndrome. Science 294:2166-2170.

Masuzaki, H, Yamamoto, H, Kenyon, CJ, Elmquist, JK, Morton, NM, Paterson, JM, Shinyama, H, Sharp MG, Fleming S, Mullins JJ, Seckl JR and Flier JS._2003.

Transgenic amplification of glucocorticoid action in adipose tissue causes high blood pressure in mice. J Clin Invest 112(1): 83-90.

McGehee RE Jr, Ron D, Brasier AR, Habener JF. 1993. Differentiation-specific element: a cis-acting developmental switch required for the sustained transcriptional expression of the angiotensinogen gene during hormonal-induced differentiation of 3T3-L1 fibroblasts to adipocytes. Mol Endocrinol. 7(4):551-60.

Michailidou, Z, Jensen, M, Dumesic, D, Seckl, JR, Walker, BR and Morton NM. 2007. Omental fat 11 beta-HSD1 is correlated with fat cell size independently of obesity. Obesity 15:1155-63

Milagro FI, Campión J, Martínez JA. 2007. 11-Beta hydroxysteroid dehydrogenase type 2 expression in white adipose tissue is strongly correlated with adiposity. $\mathbf{J}$ Steroid Biochem Mol Biol. 104(1-2):81-4.

Monder, C and White, PC 1993. 11 $\beta$-hydroxysteroid dehydrogenase. Vit Horm. 47: 187-271.

Morton NM, Holmes MC, Fiévet C, Staels B, Tailleux A, Mullins JJ, Seckl JR. 2001. Improved lipid and lipoprotein profile, hepatic insulin sensitivity, and glucose tolerance in 11beta-hydroxysteroid dehydrogenase type 1 null mice. J Biol Chem. 276(44):41293-300. 
Morton NM, Densmore V, Wamil M, Ramage L, Nichol K, Bunger L, Seckl JR, Kenyon CJ. 2005. A polygenic model of the metabolic syndrome with reduced circulating and intra-adipose glucocorticoid action. Diabetes 54(12):3371-8. Morton NM, Seckl JR. 2008. 11beta-hydroxysteroid dehydrogenase type 1 and obesity. Front Horm Res. 36:146-64.

Morton, N, Ramage, L and Seckl, J 2004a. Down-regulation of adipose 11 $\beta$ hydroxysteroid dehydrogenase type 1 by high fat feeding in mice: a potential adaptive mechanism counteracting metabolic disease. Endocrinology 145: 2707-2712. Morton, N, Paterson, J, Masuzaki, H, Holmes, MC, Staels, B, Fievet, C, Walker BR, Flier JS, Mullins, JJ and Seckl JR. 2004b. Novel adipose tissue-mediated resistance to diet induced visceral obesity in $11 \beta$-hydroxysteroid dehydrogenase type 1 deficient mice. Diabetes 53: 931-938.

Murano I, Barbatelli G, Parisani V, Latini C, Muzzonigro G, Castellucci M, Cinti S. 2008. Dead adipocytes, detected as crown-like structures, are prevalent in visceral fat depots of genetically obese mice. J Lipid Res. 49(7):1562-8.

Nair, S, Lee, Y, Lindsay, R, Walker, B, Tataranni, P, Bogardus, C, Baier, LJ, Permana PA 2004. The 11beta hydroxysteroid dehydrogenase type 1 gene: genetic polymorphisms are associated with type 2 diabetes in Pima indians independently of obesity and expression in adipocyte and muscle. Diabetologia 47: 1088-1095.

Napolitano, A, Voice, M, Edwards, CRW, Seckl, JR and Chapman, KE. 1998. 11ßhydroxysteroid dehydrogenase type 1 in adipocytes: expression is differentiationdependent and hormonally-regulated. J Steroid Biochem Molec Biol 64: 251-260. Nara N, Nakayama Y, Okamoto S, Tamura H, Kiyono M, Muraoka M, Tanaka K, Taya C, Shitara H, Ishii R, Yonekawa H, Minokoshi Y, Hara T. 2007. Disruption of CXC motif chemokine ligand-14 in mice ameliorates obesity-induced insulin resistance. J Biol Chem. 282(42):30794-803.

Nguyen MT, Favelyukis S, Nguyen AK, Reichart D, Scott PA, Jenn A, Liu-Bryan R, Glass CK, Neels JG, Olefsky JM. 2007. A subpopulation of macrophages infiltrates hypertrophic adipose tissue and is activated by free fatty acids via Toll-like receptors 2 and 4 and JNK-dependent pathways. J Biol Chem. 282(48):35279-92.

Nuotio-Antar AM, Hachey DL, Hasty AH. 2007. Carbenoxolone treatment attenuates symptoms of metabolic syndrome and atherogenesis in obese, hyperlipidemic mice. Am J Physiol Endocrinol Metab. 293(6):E1517-28.

Obeyesekere V, Alford F, Inder W.Skeletal muscle 11 \{beta\} hydroxysteroid dehydrogenase type 1 activity is upregulated following elective abdominal surgery. Eur J Endocrinol. 2008 Nov 20. [Epub ahead of print]

Ortsäter H, Alberts P, Warpman U, Engblom LO, Abrahmsén L, Bergsten P. 2005. Regulation of 11beta-hydroxysteroid dehydrogenase type 1 and glucose-stimulated insulin secretion in pancreatic islets of Langerhans. Diabetes Metab Res Rev. 21(4):359-66.

Ozcan U, Cao Q, Yilmaz E, Lee AH, Iwakoshi NN, Ozdelen E, Tuncman G, Görgün C, Glimcher LH, Hotamisligil GS. 2004. Endoplasmic reticulum stress links obesity, insulin action, and type 2 diabetes. Science. 306(5695):457-61.

Pasquali, R, Gagliardi, L, Vicennati, V, Gambineri, A, Colitta, D, Ceroni, L, Casimirri F. 1999. ACTH and cortisol response to combined corticotropin releasing hormonearginine vasopressin stimulation in obese males and its relationship to body weight, fat distribution and parameters of the metabolic syndrome. Int J Obes 23:419-424. 
Paterson, J, Morton, N, Fievet, C, Kenyon, C, Holmes, M, Staels, B, Seckl, JR and Mullins JJ. 2004. Metabolic syndrome without obesity: hepatic over-expression of 11ß-hydroxysteroid dehydrogenase type 1 in transgenic mice. Proc Natl Acad Sci (USA) 101: 7088-7093.

Paulsen SK, Pedersen SB, Fisker S, Richelsen B. 2007. 11Beta-HSD type 1 expression in human adipose tissue: impact of gender, obesity, and fat localization. Obesity (Silver Spring) 15(8):1954-60.

Pedersen SB, Jonler M, Richelsen B 1994. Characterization of regional and gender differences in glucocorticoid receptors and lipoprotein lipase activity in human adipose tissue. J Clin Endocrinol Metab; 78:1354-9.

Rask E, Walker BR, Soderberg S, Livingstone DE, Eliasson M, Johnson O, Andrew R, Olsson T. 2002. Tissue-specific changes in peripheral cortisol metabolism in obese women: increased adipose 11beta-hydroxysteroid dehydrogenase type 1 activity. J Clin Endocrinol Metab 87(7):3330-6.

Rask, E, Olsson, T, Soderberg, S, Andrew, R, Livingstone, DEW, Johnson, O, Walker, BR. 2001. Tissue-specific dysregulation of cortisol metabolism in human obesity. J Clin Endocrinol Metab. 86: 1418-1421.

Rausch ME, Weisberg S, Vardhana P, Tortoriello DV. 2008. Obesity in C57BL/6J mice is characterized by adipose tissue hypoxia and cytotoxic T-cell infiltration. Int $\mathbf{J}$ Obes (Lond). 32(3):451-63.

Rebuffat AG, Tam S, Nawrocki AR, Baker ME, Frey BM, Frey FJ, Odermatt A.2004 The 11-ketosteroid 11-ketodexamethasone is a glucocorticoid receptor agonist. Mol Cell Endocrinol. 214(1-2):27-37.

Reichardt HM, Schütz G. 1998. Glucocorticoid signalling-multiple variations of a common theme. Mol Cell Endocrinol. 146(1-2):1-6.

Ricketts, ML, Verhaeg, JM, Bujalska, I, Howie, AJ, Rainey, WE and Stewart, PM. 1998. Immunohistochemical localization of type 111 beta- hydroxysteroid dehydrogenase in human tissues. J Clin Endocrinol Metab. 83(4): 1325-1335.

Rotter V, Nagaev I, Smith U. 2003. Interleukin-6 (IL-6) induces insulin resistance in 3T3-L1 adipocytes and is, like IL-8 and tumor necrosis factor-alpha, overexpressed in human fat cells from insulin-resistant subjects. J Biol Chem. 278(46):45777-84. Rupnick MA, Panigrahy D, Zhang CY, Dallabrida SM, Lowell BB, Langer R, Folkman MJ. 2002. Adipose tissue mass can be regulated through the vasculature. Proc Natl Acad Sci U S A. 99(16):10730-5.

Sakoda H, Ogihara T, Anai M, Funaki M, Inukai K, Katagiri H, Fukushima Y, Onishi Y, Ono H, Fujishiro M, Kikuchi M, Oka Y, Asano T. 2000. Dexamethasone-induced insulin resistance in 3T3-L1 adipocytes is due to inhibition of glucose transport rather than insulin signal transduction. Diabetes. 49(10):1700-8.

Sandeep, TC, Andrew, R, Homer, NZM, Andrews, RC, Smith, K and Walker, BR. 2005. Increased in vivo regeneration of cortisol in adipose tissue in human obesity and effects of the 11 beta-hydroxysteroid dehydrogenase type 1 inhibitor carbenoxolone. Diabetes 54: 872-879.

Sartipy P, Loskutoff DJ. 2003. Monocyte chemoattractant protein 1 in obesity and insulin resistance. Proc Natl Acad Sci U S A. 100(12):7265-70.

Schweizer RA, Zurcher M, Balazs Z, Dick B, Odermatt A. 2004. Rapid hepatic metabolism of 7-ketocholesterol by 11 beta-hydroxysteroid dehydrogenase type 1 : species-specific differences between the rat, human, and hamster enzyme. J Biol Chem. 279(18):18415-24. 
Seckl JR, Walker BR. 2001. Minireview: 11beta-hydroxysteroid dehydrogenase type 1- a tissue-specific amplifier of glucocorticoid action. Endocrinology. 142(4):1371-6.

Senesi S, Marcolongo P, Manini I, Fulceri R, Sorrentino V, Csala M, Bánhegyi G, Benedetti A. 2008.Constant expression of hexose-6-phosphate dehydrogenase during differentiation of human adipose-derived mesenchymal stem cells. J Mol Endocrinol. 41(3):125-33.

Sewter, CP, Blows, F, Vidal-Puig, A and O'Rahilly, S. 2002. Regional differences in the response of human pre-adipocytes to PPAR gamma and RXR alpha agonists. Diabetes 51(3): 718-723.

Shi H, Kokoeva MV, Inouye K, Tzameli I, Yin H, Flier JS. 2006. TLR4 links innate immunity and fatty acid-induced insulin resistance. J Clin Invest. 116(11):3015-25.

Shimomura, Y, Bray, GA and Lee M. 1987. Adrenalectomy and steroid treatment in obese (ob/ob) and diabetic (db/db) mice. Horm Metab Res 19, 295-9.

Singh S, Loke YK. 2008. The safety of rosiglitazone in the treatment of type 2 diabetes. Expert Opin Drug Saf. 7(5):579-85.

Slavin BG, Ong JM, Kern PA. 1994. Hormonal regulation of hormone-sensitive lipase activity and mRNA levels in isolated rat adipocytes. J Lipid Res. 35(9):1535-41. Small GR, Hadoke PW, Sharif I, Dover AR, Armour D, Kenyon CJ, Gray GA, Walker BR. 2005. Preventing local regeneration of glucocorticoids by 11 betahydroxysteroid dehydrogenase type 1 enhances angiogenesis. Proc Natl Acad Sci USA 102(34):12165-70.

Smith AG, Muscat GE. 2005. Skeletal muscle and nuclear hormone receptors: implications for cardiovascular and metabolic disease. Int J Biochem Cell Biol. 37(10):2047-63.

Song MJ, Kim KH, Yoon JM, Kim JB. 2006. Activation of Toll-like receptor 4 is associated with insulin resistance in adipocytes. Biochem Biophys Res Commun. 4; 346(3):739-45.

Steppan, C, Bailey, S, Bhat, S, Brown, E, Banerjee, R, Wright, C, Patel, HR, Ahima, RS Lazar, M. 2001. The hormone resistin links obesity to diabetes. Nature 409: 307312.

Stewart, PM, Boulton, A, Kumar, S, Clark, PMS and Shackleton, CHL. 1999.

Cortisol metabolism in human obesity: Impaired cortisone $->$ cortisol conversion in subjects with central adiposity. J Clin Endocrinol Metab 84:1022-1027.

Stimson RH, Andersson J, Andrew R, Redhead DN, Karpe F, Hayes PC, Olsson T, Walker BR. 2008. Cortisol release from adipose tissue by 11 \{beta\}-hydroxysteroid dehydrogenase type 1 in humans. Diabetes. (epub ahead of print).

Swali A, Walker EA, Lavery GG, Tomlinson JW, Stewart PM. 2008. 11betaHydroxysteroid dehydrogenase type 1 regulates insulin and glucagon secretion in pancreatic islets. Diabetologia. 51(11):2003-11.

Tannin GM, Agarwal AK, Monder C, New MI, White PC. 1991. Cloning and sequencing of the human cDNA for corticosteroid 11-beta-dehydrogenase. The human gene for 11 beta-hydroxysteroid dehydrogenase. Structure, tissue distribution, and chromosomal localization. J Biol Chem. 266(25):16653-8.

Taylor A, Irwin N, McKillop AM, Flatt PR, Gault VA. 2008. Sub-chronic administration of the 11beta-HSD1 inhibitor, carbenoxolone, improves glucose tolerance and insulin sensitivity in mice with diet-induced obesity. Biol Chem. 389(4):441-5. 
Thieringer R, Le Grand CB, Carbin L, Cai TQ, Wong B, Wright SD, HermanowskiVosatka A. 2001. 11 Beta-hydroxysteroid dehydrogenase type 1 is induced in human monocytes upon differentiation to macrophages. J Immunol. 167(1):30-5.

Tomlinson JW, Sherlock M, Hughes B, Hughes SV, Kilvington F, Bartlett W, Courtney R, Rejto P, Carley W, Stewart PM. 2007. Inhibition of 11 betahydroxysteroid dehydrogenase type 1 activity in vivo limits glucocorticoid exposure to human adipose tissue and decreases lipolysis. J Clin Endocrinol Metab. 92(3):85764.

Tomlinson, JW, Sinha, B, Bujalska, I, Hewison, M and Stewart, PM. 2002. Expression of 11 beta-hydroxysteroid dehydrogenase type 1 in adipose tissue is not increased in human obesity. J Clin Endocrinol and Metab 87(12): 5630-5635.

Tomlinson JW, Walker EA, Bujalska IJ, Draper N, Lavery GG, Cooper MS, Hewison M, Stewart PM. 2004 11beta-hydroxysteroid dehydrogenase type 1: a tissue-specific regulator of glucocorticoid response. Endocr Rev. 25(5):831-66.

Uddén J, Eriksson P, Hoffstedt J. 2002.Glucocorticoid-regulated adipose tissue secretion of PAI-1, but not IL-6, TNFalpha or leptin in vivo. Horm Metab Res. 34(1112):698-702.

Udden, J, Folkesson, R and Hoffstedt, J Downregulation of uncoupling protein 2 mRNA in women treated with glucocorticoids. Int J Obes 2001; 25(11): 1615-1618. Wajchenberg BL: 2000. Subcutaneous and visceral adipose tissue: their relation to the metabolic syndrome. Endocr Rev 21:697-738.

Wake, DJ, Rask, E, Livingstone, DEW, Soderberg, S, Olsson, T and Walker, BR. 2003. Local and systemic impact of transcriptional up-regulation of 11 betahydroxysteroid dehydrogenase type 1 in adipose tissue in human obesity. J Clin Endocrinol Metab 88(8): 3983-3988.

Walker, BR, Connacher, AA, Lindsay, RM, Webb, DJ and Edwards, CRW. 1995. Carbenoxolone increases hepatic insulin sensitivity in man: A novel role for 11oxosteroid reductase in enhancing glucocorticoid receptor activation. J Clin Endocrinol and Metab 80: 3155-3159.

Wamil M, Andrew R, Chapman KE, Street J, Morton NM, Seckl JR. 2008.7Oxysterols Modulate Glucocorticoid Activity in Adipocytes through Competition for 11 beta\}-Hydroxysteroid Dehydrogenase Type. Endocrinology. 149(12):5909-18.

Wang SJ, Birtles S, de Schoolmeester J, Swales J, Moody G, Hislop D, O'Dowd J, Smith DM, Turnbull AV, Arch JR. 2006. Inhibition of 11 beta-hydroxysteroid dehydrogenase type 1 reduces food intake and weight gain but maintains energy expenditure in diet-induced obese mice. Diabetologia. 49(6):1333-7.

Weisberg SP, McCann D, Desai M, Rosenbaum M, Leibel RL, Ferrante AW Jr. 2003. Obesity is associated with macrophage accumulation in adipose tissue. J Clin Invest. 112(12):1796-808.

Wellen KE, Hotamisligil GS. 2005. Inflammation, stress, and diabetes. J Clin Invest. 115(5):1111-9.

WHO 2008a www.who.int/features/factfiles/global_burden/facts/en/index1.html (cadiovascualr disease).

WHO 2008 b www.who.int/mediacentre/factsheets/fs311/en/index 1 (obesity).

Whorwood CB, Donovan SJ, Wood PJ, Phillips DI. 2001. Regulation of glucocorticoid receptor alpha and beta isoforms and type I 11beta-hydroxysteroid dehydrogenase expression in human skeletal muscle cells: a key role in the pathogenesis of insulin resistance?J Clin Endocrinol Metab. 86(5):2296-308. 
Whorwood, CB, Franklyn, JA, Sheppard, MC and Stewart, PM. 1991. Tissue localization of 11B-hydroxysteroid dehydrogenase and its relationship to the glucocorticoid receptor. J Steroid Biochem Molec Biol. 41: 21-28.

Wolf G. 1999. The molecular mechanism of the stimulation of adipocyte differentiation by a glucocorticoid. Nutr Rev. 57(10):324-6.

Wu H, Ghosh S, Perrard XD, Feng L, Garcia GE, Perrard JL, Sweeney JF, Peterson LE, Chan L, Smith CW, Ballantyne CM. 2007. T-cell accumulation and regulated on activation, normal $\mathrm{T}$ cell expressed and secreted upregulation in adipose tissue in obesity. Circulation 115(8):1029-38.

Xu H, Barnes GT, Yang Q, Tan G, Yang D, Chou CJ, Sole J, Nichols A, Ross JS, Tartaglia LA, Chen H. 2003. Chronic inflammation in fat plays a crucial role in the development of obesity-related insulin resistance. J Clin Invest. 112(12):1821-30.

Xu HE, Lambert MH, Montana VG, Parks DJ, Blanchard SG, Brown PJ, Sternbach DD, Lehmann JM, Wisely GB, Willson TM, Kliewer SA, Milburn MV. 1999.

Molecular recognition of fatty acids by peroxisome proliferator-activated receptors. Mol Cell 3(3): 397-403.

Xu HE, Lambert MH, Montana VG, Parks DJ, Blanchard SG, Brown PJ, Sternbach DD, Lehmann JM, Wisely GB, Willson TM, Kliewer SA, Milburn MV. 1999.

Yacoub Wasef SZ, Robinson KA, Berkaw MN, Buse MG. 2006. Glucose, dexamethasone, and the unfolded protein response regulate TRB3 mRNA expression in 3T3-L1 adipocytes and L6 myotubes. Am J Physiol Endocrinol Metab. 291(6):E1274-80.

Yamauchi T, Kamon J, Minokoshi Y, Ito Y, Waki H, Uchida S, Yamashita S, Noda M, Kita S, Ueki K, Eto K, Akanuma Y, Froguel P, Foufelle F, Ferre P, Carling D, Kimura S, Nagai R, Kahn BB, Kadowaki T. 2002. Adiponectin stimulates glucose utilization and fatty-acid oxidation by activating AMP-activated protein kinase. Nat Med 8: 1288-1295.

Ye J, Gao Z, Yin J, He Q. 2007. Hypoxia is a potential risk factor for chronic inflammation and adiponectin reduction in adipose tissue of ob/ob and dietary obese mice. Am J Physiol Endocrinol Metab. 293(4):E1118-28.

Zeyda M, Farmer D, Todoric J, Aszmann O, Speiser M, Györi G, Zlabinger GJ, Stulnig TM. 2007. Human adipose tissue macrophages are of an anti-inflammatory phenotype but capable of excessive pro-inflammatory mediator production. Int J Obes (Lond). 31(9):1420-8. Epub 2007 Jun 26.

Zhang TY, Daynes RA. 2007. Macrophages from 11beta-hydroxysteroid dehydrogenase type 1-deficient mice exhibit an increased sensitivity to lipopolysaccharide stimulation due to TGF-beta-mediated up-regulation of SHIP1 expression. J Immunol. 179(9):6325-35.

Zhang TY, Ding X, Daynes RA. 2005 The expression of 11 beta-hydroxysteroid dehydrogenase type I by lymphocytes provides a novel means for intracrine regulation of glucocorticoid activities. J Immunol. 174(2):879-89. 


\section{Figure Legends}

\section{Figure 1.}

Metabolic Consequences of Adipose Tissue Hypertrophy in Obesity. Fat cells (yellow circles) undergo hypertrophy in response to excess calories. This leads to insulin resistance, cellular stress and eventually cell death. Fat cell expansion outstrips the necessary vascular supply leading to impaired angiogenesis and hypoxia. Hypertrophy is associated with release of chemokines/adipokines that attract orchestrating T-(cytotoxic) cells and subsequently pro-inflammatory macrophages. Adipocyte insulin resistance causes further increased release of free fatty acids which exacerbate the insulin resistance locally by binding to pro-inflammatory toll-like receptors (tlrs, brown lollipop shape) on adipocytes and by promoting activation and cytokine release from infiltrating macrophages recruited to the inflammatory milieu. High free fatty acids, pro-inflammatory adipokines/chemokines and reduced adiponectin contribute to systemic insulin resistance.

\section{Figure 2.}

\section{Effects of Elevated 11 $\beta$-HSD1 on Adipocyte Function in Obesity.}

1. Inactive cortisone from the blood is converted to active cortisol by $11 \beta$-HSD1 within the cell. 2. This promotes preadipocyte differentiation, which contributes to (central) obesity during caloric excess. 3. As adipocytes become hypertrophic, 11ßHSD1 levels and intracellular cortisol levels rise causing the following hypothetical effects within the adipocyte (clockwise from far left): increased (+) LPL expression (lpl) and lipid uptake; impaired (-) angiogenic vascularisation responses from surrounding blood vessels; suppression (-) of AMPKinase, with a consequent increase in (+) lipogenesis and reduction (-) in fat oxidation; increased (+) ER stress; a variable effect on adipokine secretion including increased (+) angiotensinogen (angtn), which leads to hypertension, and suppression (-) of adiponectin, which exacerbates systemic insulin resistance; direct impairment of the insulin signalling cascade (eg IRS 1 or 2) and insulin-responsive glucose uptake (GluT4); increased (+) lipolysis through HSL; spillover of locally produced cortisol which may affect neighbouring cells and contribute to insulin resistance in other organs (eg portal drainage to the liver). 4. Competitive metabolism of cholesterol metabolites and glucocorticoids may lead to accumulation of atherogenic oxysterols $(7-\mathrm{kC}=7$ ketocholesterol, 7-ohC $=7$ hydroxycholesterol) within the fat/systemically. 
Figure 1 Metabolic Consequences of Adipose Tissue Hypertrophy in Obesity

\section{Normal \\ Obesity}

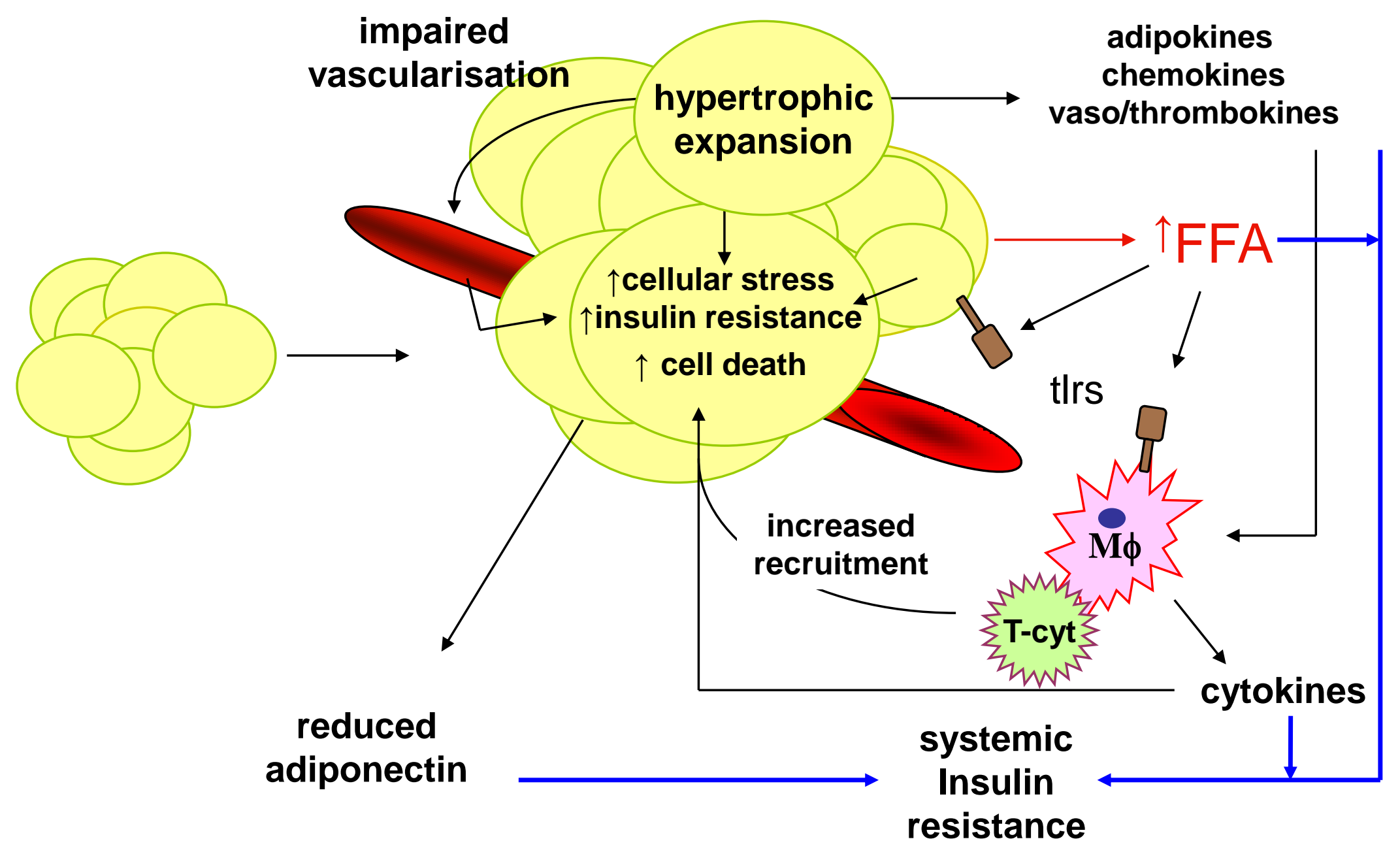


Figure 2. Effects of Elevated 11 $\beta$-HSD1 on Adipocyte Function in Obesity.

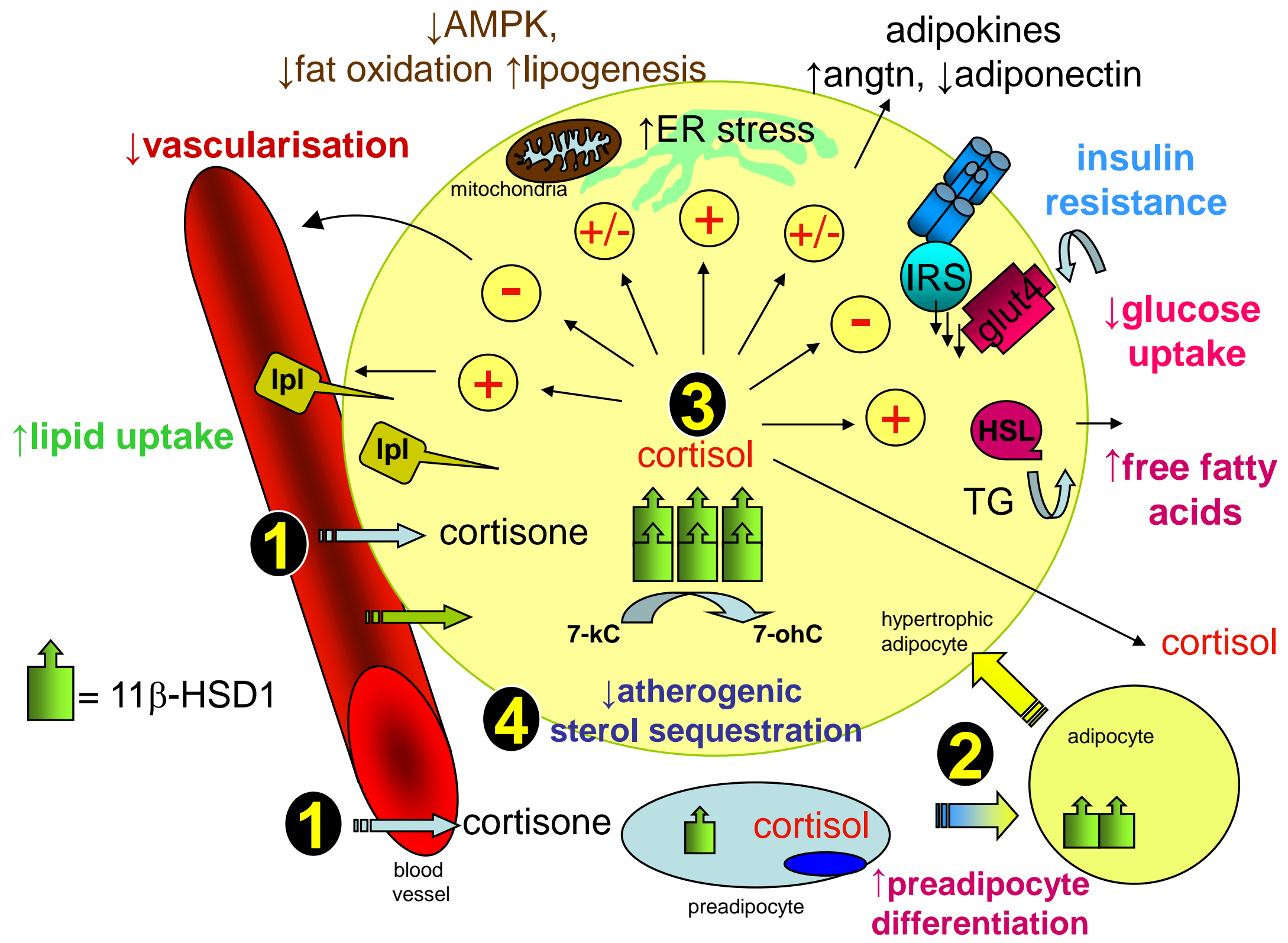

